\title{
Market Concentration and Performance of Chinese Film Industry Based on SCP Paradigm
}

\author{
Biao Xu \\ School of North China Power University, Baoding 071000, China. \\ 18632016554@163.com
}

\begin{abstract}
With the continuous improvement of Chinese urban per capita national income, leisure and entertainment has become an important part of people's life, and the entertainment expenditures are accounting for an increasing proportion of total consumption. Movies, as a leisure project, has attracted more and more Chinese people' interest. At present, China is the second largest film market in the world, which is fast growing. According to the PWC's report in 2014, in 2018, Chinese film box office revenue will increase by $88 \%$, from $\$ 31.3$ billion in 2013 to $\$ 59$ billion. It is suggesting that Chinese film industry has a bright prospect. This paper uses SCP paradigm of industrial organization theory to research China's film industry. We find that: Chinese film production market is a competitive market; the film issuing market is oligopolistic, type III market; and the film cinema market belongs to an oligopolistic, type IV market. At the same time, the film market behavior and market performance analysis shows that China's film market is in the stage of vigorous development. Finally, this paper proposes several suggestions for the development of China's film industry.
\end{abstract}

Keywords: Film industry; market structure; market performance; market behavior.

\section{Introduction}

With the continuous improvement of Chinese urban per capita national income, movies, as a leisure project, has attracted more and more Chinese people' interest. At present, China is the second largest film market in the world, which is fast growing. According to the PWC's report in 2014, in 2018 , Chinese film box office revenue will increase by $88 \%$, from $\$ 31.3$ billion in 2013 to $\$ 59$ billion. It is suggesting that Chinese film industry has a bright prospect. This paper uses SCP paradigm of industrial organization theory to research China's film industry. We find that: Chinese film production market is a competitive market; the film issuing market is oligopolistic, type III market; and the film cinema market belongs to an oligopolistic, type IV market. At the same time, the film market behavior and market performance analysis shows that China's film market is in the stage of vigorous development. Finally, this paper proposes several suggestions for the development of China's film industry.

In 1959, Bain, Kaysen and Turner, which were called as "Harvard School", proposed empirical research as the main means of the industrial analysis, and there are three aspects: the structure, conduct, performance, which is denominated SCP paradigm analysis framework, to analyze a specific industry, and through the public policy of the government to adjust the competition pattern of the industry.

At present, there are many scholars studying the competitiveness evaluation, industrial organization, experience in trade and industry chain of China's film industry. Among them, Dong Xiao Lin and $\mathrm{Wu}$ Shan, in American movie industry trade experience and of China's film trade revelation, revealed the development experience and inspiration of the American film industry trade for China film industry and found out the effective way to promote the globalization development of China's film industry. Gao Cheng, in High osmium based on the SCP analysis framework, China Film Industry Research, used SCP paradigm to study China's film industry, but the data was before 2005, coupled with the rapid development of the industry in the recent years, the research is slightly outdated. In view of the film industry of our country, the present cultural life of the residents, and the recreational importance of the industry, further analysis of the film industry's market concentration and performance will undoubtedly have a significant importance. 


\section{Market Concentration of Chinese Film Industry Based on SCP Paradigm}

According to the State Press and Publication Administration of Radio's statistics of film and television, the top 15 in 2014 film production organizations accounted for about $30 \%$ of the market share, and accounted for an average of more than $2 \%$.As the market is dispersed, intersubjective disparity discrimination is not enough, and the leading strength is limited. The traditional film production institutions, such as China Film Group Corporation with a number of advantages, continue to maintain a leading position; Wanda Media Co. Ltd gauges overweight aspects of film production, ranking first in the private companies; Enlight Media main dispersing, Huayi Bros. Media Group, implementation to the film strategy, resulting in two share accounted for the decline. The 1905 Movie Net, as the subsidiary company of movie channel in Transformers 4 high box office boost, enjoys the fastest rising market, and enters the year's biggest five. Cultural investment company of the canopy moon in annual domestic box office champions Be wild with Joy produced, and enjoys a share of $1.27 \%$. In the TV series industry, Zoomlion UNITA, Huace film gauge, Tende international in the good film industry, under the linkage effect of film and television, have entered the top ten.

Market concentration is the most basic and most important factor to determine the structure of the market. It embodies the market competition and the degree of monopoly. Usually, we use absolute concentration index to express (Table 1).

Absolute degree of concentration generally refers to the relevant indicators of the largest number of enterprises in the industry accounting for the market as a whole, the formula is:

\begin{tabular}{ccc}
$C R_{n}=\frac{i=1}{N} x_{i}$ \\
$x_{i}$ \\
$C R_{4}^{\text {producer }}=4.08 \%+3.17 \%+2.57 \%+2.43 \%=12.25 \%$ & & \\
$C R_{4}^{\text {issue }}=32.80 \%+22.89 \%+7.75 \%+5.99 \%=69.43 \%$ & & \\
$C R_{4}^{\text {cinema }}=(42.0837+24.4531+23.5094+22.0732)$ & $296.39=37.8283 \%$ & \\
Table 1 Bain's market structure classification & $\mathrm{CR}_{8}(\%)$ \\
\hline CR & $\mathrm{CR}_{4}(\%)$ & - \\
\hline oligopolistic industry type I & $85-100$ & $85-100$ \\
oligopolistic industry type II & $75-85$ & $75-85$ \\
oligopolistic industry type II & $50-75$ & $45-75$ \\
oligopolistic industry type IV & $35-50$ & $40-45$ \\
oligopolistic industry type V & $30-35$ & $0-40$ \\
competition type & $0-30$ & \\
\hline
\end{tabular}

According to $0<\mathrm{CR}_{4}{ }^{\text {producer }}<30 \%$, film production market belongs to the competitive market; $50 \%<\mathrm{CR}_{4}{ }^{\text {issuse }}<75 \%$, movie film market is oligopoly type III market; $35 \%<\mathrm{CR}_{4}{ }^{\text {cinema }}<50 \%$, cinema market belongs to oligopoly type IV market. By the above various $\mathrm{CR}_{4}$ value, we can be determined, China's film industry, the different markets' concentration degree are different. Strong competition in the production market activity, market efficiency imposes a higher state, in favor of allocation of resouces. Cinema market concentration is relatively high, the vigor of competition is relatively low, belonging to the monopolistic competition market. Issue market concentration degree is high, still has a large room for improvement in the future. It should avoid high degree of monopoly, which resulting loss in social welfare.

Product differentation means that in the same industry, to provide to the customer products, through a variety of methods to initiate customer preference, so that customers can put it with the other competitive enterprises which offering similar products, thus enterprises in market competition can occupy a favorable position.

(1) Brand differentiation: The brand is the cinema's most important intangible assets. At present, chinese film industry has formed a certain number of brands. Wanda Cinema has followed the core concept of business services all to the value of the viewing audience and the viewing experience. United Cinema following as "people-oriented, honest and efficient, scientific and technological 
innovation", and managing to creat Shanghai Alliance Cinema as a first-class Chinese Cinema. Brand differences making different preferences of customers satisfied, and the location of theaters also giving people more choices, though the movie theaters can attract and retain more loyal customers.

(2) Price discrimination: Price war is the current market business most important means of competition. Different cinemas, as their different positioning of consumer positioning, will naturally cause the price difference. In Baoding as an example, we treating speed and passion 7 for comparison, the ticket price of Huali Studio, Palme d'Or international Studio and Wanda Film are 40 yuan, Shidaijinqiu is 30 yuan. China Studio's popcorn is 10 yuan a barrel, the Palme d'Or International Studio is 20 yuan a barrel, Wanda Studio is 30 yuan. Thus, the price discrimination is also an important embodiment of product differentiation.

Entry barrier refers to the extent to which an enterprise has a certain advantage in its potential to enter the enterprise and the new enterprise that has just entered the industry.

In the structural entry barriers, first of all, the film company has absolute cost advantage. Has gone through recently development years, the existing enterprise business model has been basically mature, and has ability to lower the cost of operating. Nowaday, Wanda and other large enterprises have distributed network all over the country, formed scale economy. Secondly, operating a film company's capital requirements is also puzzled ready to enter the market vendors. Furthermore, current film companies through advertising and other means to build consumer loyalty; At the same time, in the matter of sale channels, incumbents has obvious advantages. Finally, network effects of barriers equally underestimated. Due to the positive externality of consumption, namely message among consumers expansion, making the consumers increasing will enhance the utility level of consumers, and increasing consumer demand for the goods.

In the strategic entry barriers, on the one hand, a successful enterprise, enterprise learning effect is essential. At present, the movie industry due to the long-term course of business, the accumulation of production experience making the production efficiency of enterprises continuously improving, average production costs dropping significantly. On the other hand, the movie related enterprises continue to create their own customers, inceasingly carries on the market segmentation to improve the conversion cost, making ready to enter the business risk increased significantly.

\section{Market Behavior and Performance of Chinese Film Industry}

Market behavior refers to various decision-making behavior that enterprises take into full consideration of the supply and demand conditions of the market and the relationship of other enterprises.

\subsection{Pricing Behavior.}

In order to maintain or improve the film companies' influence and market share, general decision makers may will be taken measures to limit the pricing method.

We set Wanda's cinema as a case, for example, Wanda's market share in the film industry is the first, except the movie box office income, in 2014, Wanda's goods for sale (popcorn, drinks, etc.) and advertising business were obtained 6.3 million and 5.2 billion yuan. Wanda cinema show business gross profit rate is only $20 \%$, sales of goods (that is people often say that the "sell popcorn income") gross profit rate is as high as $70 \%$. Different ordinary industry from business model, the film industry's profitability is diversified, more to increase the waiting to enter the industry costs, and high investment, returns low and commodity sales channels problems, further limiting the entry of new firms.

At the same time, price discrimination is also pricing behavior important reflect. Film enterprise decision makers will classified consumers into several different groups (such as students, buy group, etc.), and charges different prices to different consumer groups. Different consumers have different price sensitive degree, manufacturers according to this characteristics, making price segments, grabbing more consumer surplus to obtain more profits. 


\subsection{Innovation and $R \& D$ Behavior.}

With the vigorous development of the film industry, people, treated the film's attitude, has been changing. Now the movie is not only exciting plot, a collection of favorite stars, but also changing to the reaction regarding as people for a better life, which requires the cinema to provide better service to meet the cultural needs of the people' growing. So $4 \mathrm{D}$, dome screen projection system, inflatable cinema and interactive movies continues to develop.

The market performance refers to in certain market structure, formed by a certain market behavior of prices, production, cost, profit, the quality of the products and technology progress in the ultimate economic results. Reflecting the market operation results of specific market structure and market behavior,.

In terms of the size of the film, to reflect the market demand of the total box office index, since 2009 , is rapidly growing, reaching an average of $40 \%$ of the growth, 2014 has been close to 300 billion yuan. But at the same time, we must see, chinese film industry exports accounted for the ratio decreased year by year, until now has basically lost the market abroad, this deserves our profound reflection.

At the same time, domestic and imported films at the box office with the net difference in 20092011 remained in $8-12 \%, 2012$ is the counter ultra $-4 \%, 2013$ recovered after widening to $18 \%, 2014$ achieving regression, returned to the average range. In domestic films, row piece protection policies and film review mechanism background, it is expected to subsequent years domestic tablets and imported tablets with difference will continue to maintain in the average range. From domestic, imported films at the box offic's growth, their average growth rate is $37 \%, 40 \%$ respectively, but the former to the Chinese film total box office is lower than the latter, domestic films need to further improve the competitiveness.

\section{Summary}

In this paper, through the study of the Chinese film industry market concentration and market performance, the main conclusions are drawn as follows:

First, film has no doubt commercial property, industrialization is the inevitable trend of the development. But in general, industrial reforming of Chinese movie industry still lags behind.Second, the different markets' concentration of China's film industry are different.Third, product differentiations of the film industry are obvious, and there are obvious manifestations in the brand, price, service, channel, promotion and so on. Forth, the barriers to entry of China's film industry is high, the potential investors have higher cautious attitude. Fifth, chinese film markets have significant differences in pricing behavior, advertising behavior, mergers and acquisitions, innovation and R\&D behavior and market coordination behavior, as well as the market continues to progress. Sixth, the Chinese film industry has developed rapidly in recent years and will continue to develop.

In order to accelerate the development of the film industry, we put forward some suggestions:First, speeding up the construction of relevant laws and regulations of movie.Second, adhereing to the film audit system and increasing the national support of the film industry. Third, insist the new situation for internet plus film, and intensifying to exploit the countryside movie market. Forth, combating piracy, cultivating the cinema film market and the habits of the people. Fifth, broadening the financing channels of the film industry, promoting the extension of the movie industrial value chain. Sixth, expanding the proportion of the film industry in the national economy. Seventh, actively and prudently enlarging the effective screen number. Eighth, appropriately controlling movie reproduction quantity.

\section{References}

[1]. Yang Gongpu, Xia Da, Gong Yangjun, Industrial Economics Tutal, 2008, Third Edition.

[2]. Gao Cheng, The Chinese Mainland Film Industry Research Based on the Analysis Framework of $S C P$.

[3]. Grace Consulting, The Chinese Film Industry Research Report, 2015. 